\title{
Literary Research
}

www.ijrap.net

\section{AMA A METABOLIC BYPRODUCT WITH SPECIAL REFERENCE TO AMAVATA}

Mishra Pramod Kumar ${ }^{1 *}$, Rai N.P. ${ }^{2}$

${ }^{1}$ Department of Kayachikitsa, Faculty of Ayurveda, Banaras Hindu University, Varanasi, U.P., India

${ }^{2}$ Head of the Department of Kayachikitsa, Faculty of Ayurveda Banaras Hindu University, Varanasi, U.P., India

Received on: 30/07/13 Revised on: 12/09/13 Accepted on: 29/09/13

\author{
*Corresponding author \\ E-mail: shandilyapk11@gmail.com \\ DOI: 10.7897/2277-4343.04511 \\ Published by Moksha Publishing House. Website www.mokshaph.com \\ All rights reserved.
}

\section{ABSTRACT}

In this modern era sedentary life style, faulty food habits and stressful jobs are giving rise to so many diseases. These conditions have direct impact on agni and this impaired state of agni produces ama. Ama generates acute diseases and chronic conditions as well. Amavata is one of such chronic state of ama. Rheumatoid arthritis in modern system of medicine is the disease which can be correlated to amavata as symptoms of amavata are similar to those of rheumatoid arthritis. So, in conformity with time, it is important to understand ama and amavata.

Keywords: agni, ama, amadosha, amavata, rheumatoid arthritis, free radicals.

\section{INTRODUCTION}

There are two main objectives of Ayurveda-maintaining health of individual and alleviating ailments of diseased. ${ }^{1}$ Sushruta says, one whose doshas (humors), agni (digestive fire), dhatu (body tissue) and malas (by products of metabolism) are in balanced state and whose senses, mind and soul are functioning properly is a healthy individual. ${ }^{2}$ While doshas, dhatus and malas are basic constituents of the body ${ }^{3}$ agni maintains the physiology of this deha desha (milieu interior). In other words agni controls the state of biological equilibrium of dosha, dhatu and mala. Depicting importance of agni Charaka says ${ }^{4}$-life span, complexion, strength, health, enthusiasm, corpulence, luster, immunity, energy, heat process and vital breath, all these depend on agni. One dies, if this fire is extinguished, lives long free from disorders, if it is functioning properly and gets ill, if it is deranged. Further he $\operatorname{adds}^{5}$ that food nourishing dhatus, ojas, strength, complexion etc. depends on agni because rasa and other dhatus can't be produced from undigested food. The derangement of agni produces undigested material which is called as ama. Main cause of this derangement is faulty food habit, sedentary life style and stress which are gift of this modern era. Nearly all diseases in Ayurveda are due to feeble action of agni ${ }^{6}$ and thus amadosha.

\section{Aim and Objective}

- To evaluate the concept of ama as per Ayurveda.

- To establish the relation of ama with metabolic by product.

- To understand the pathogenesis of amavata by ama.

\section{MATERIAL AND METHOD}

Literary references from Ayurvedic and modern literature were collected and analytically reviewed to establish correlation between ama and metabolic by-products with special reference to amavata.

\section{DISCUSSION}

Understanding the Ama

The term ama in ordinary parlance means unripe, uncooked, immature undigested or unprocessed substance. In context of medicine, it is a consequence of impaired functioning of jatharagni (digestive fire). According to Vagbhata ${ }^{7}$ due to hypo functioning of the agni the first dhatu viz. the rasa is not properly formed. As a result the annarasa undergoes fermentation which is retained in amashaya (stomach). This state of rasa is called as ama. Again referring to other authorities, Vagbhata says ${ }^{8}$ 'the impaired doshas being mixed up with one another lead to the formation of amadosha just like production of visha (toxic substances) by the spoilt kodrava'. Vijayrakshita in the chapter on amavata quoted a number of definitions and commented very intelligently on amadosha: ${ }^{9}$

- If annarasa is not properly digested and formed then the outcome of such a digestion is known as ama.

- The impairment of jatharagni in amashaya results in improperly formed annarasa which is called as ama.

- Due to poor strength of jatharagni a residue of ahararasa is left behind undigested at the end of digestion; it is known as ama, which is the root cause of all diseases.

- There are others who hold, that the undigested annarasa possessing foul odour and excessive pastiness deprives the body of its nutrition and in consequence causes, sadana (malaise). This undigested annarasa is known as ama.

- Some describe ama as improperly digested food; some say it is accumulation of malas, while in view of others ama is a first stage of dosha-dushti.

\section{Accumulation of Malas}

Two types of malas are produced in the body. One which is known as sthula mala, a byproduct of ahara-paka viz. purisha (faeces), mutra (urine) and sweda (sweat), second, 
which is termed as sukshma mala which is the result of dhatu-paka like kapha, excretory products in the apertures, nails, hair etc. If these malas start accumulating in the body and srotas (micro channels), will cause obstruction in micro channels (sroto-avarodha). These being in excess, exert adverse effect on digestion and metabolism and acclaimed as ama. In this context it also indicates that excess accumulation of blood urea, uric acid etc. that are metabolic by-products may lead to various disorders. So these metabolic by-products can be considered as ama.

\section{Ama, the First Stage of Dosha-dushti}

The first stage of vitiation of dosha is known as sanchayavastha. In this stage, dosha start accumulating in their own places. The massive increase of dosha is chaya. ${ }^{10}$ Due to chaya, aggravated doshas, fill their normal srotasa completely. This further leads to disturbance in jatharagni causing formation of ama.

\section{Etiological Factors}

Charaka has very elaborated view regarding etiology and pathogenesis of ama. He says that not only food taken in excess quantity cause production of ama but heavy, cold, dry, impure etc. diets may also cause ama. He also indicates mental factors causing ama like anger, greed, jealousness, grief, fear etc. Intake of wholesome food in proper quantity do not get properly digested when individual is afflicted with these mental conditions. ${ }^{11}$ Again the impairment of agni may be brought about by abstinence from food, indigestion, never-eating, irregular diet habits, indulgence in incompatible food items, the consumption of cold substances, mal-effects of virechana (purgation), vamana (emesis), snehana (oleation), wasting of tissue due to diseases, unfavorable changes in place, climate, season and suppression of natural urges cause impairment of agni which fails to digest even the most easily digestible light food. Thus, the undigested food attains shuktatva (fermentation) leading to the onset of toxic state. ${ }^{12}$ Thus produced ama when get amalgamated with tridoshas and dhatus as well as mala, a condition called sama is producd. ${ }^{13}$ Wherever ama situated and vitiated by doshas it produces respective symptoms and disease. ${ }^{14}$ Two different terminologies are used in context to ama viz. amadosha and amapradosha. ${ }^{15}$ Gangadhara says that resulting action of ama inside the body is called amadosha. Chakrapani says manifestation of certain reaction inside the body due to under processed annarasa is called amapradosha.

\section{Biophysical Properties of Ama}

In Sarvangasundara, (a commentary on Astanga Hridaya) it is said that ama is liquid, heavy, different colors, slimy, viscid, thread, sticky, yields foul smell, increased sourness, thick turbid and obstructing various pathways etc. Ama can be produced at various levels. When it manifests due to sluggish function of jatharagni it causes so many diseases of gastro-intestinal origin like vishuchika (gastroenteritis), atisara (diarrhea) etc. Altered functions of dhatvagni cause dhatu-pradoshaja disease like rasa-pradoshaja (fever, pallor, reduction in strength, impotency, premature graying of hairs and appearance of wrinkles etc.) rakta-pradoshaja (leprosy, pimples, hemorrhages, moles, warts) etc. Due to improper functioning of dhatvagni sama dhatu is formed i.e. sama rasa, sama meda etc. These incompletely formed dhatus may also hamper nutrition of next consecutive dhatu to be nourished. When there is defect in the function of bhutagni, it will not be able to digest pancha-bhautic ahara guna like apya, bhaumya, agneya etc. further causing defective assimilation of the food. ${ }^{16}$ The spectrum of disease occurs due to ama ranging from acute to chronic one. This ama produces acute disorders of the alimentary system like ajirna (indigestion), vishuchika (gastroenteritis), jwara (fever), atisara (diarrhoea) etc. Among the subacute and chronic one both gastrointestinal and metabolic diseases occurs viz. grahani dosha, udararoga, amavata, pandu, prameha etc. ${ }^{17}$ Taking amavata in consideration here is a short explanation of it: Amavata is chronic condition of ama. When ama get situated in joints due to long time practice of faulty food habits and life styles the disease is produced. It is a disease of pain and inflammation in joints. It affects all small and big joints. ${ }^{18}$ In modern system of medicine its very clinical correlate is rheumatoid arthritis. Amavata is a disease of ama and vata. Dietary indiscretions, lack of physical activity, impairment of agni are some causative factors of amavata. ${ }^{19}$ These factors actually produce ama which is carried by vayu (air) and takes specially seat of kapha. After vitiation by all the three doshas it is being spread by vessels throughout body. ${ }^{20}$ Ama mixed with tridosha obstructs all the srotasa due to which vayu is vitiated. Cause of vayu vitiation is blockade of its path by ama (margavarodha). So the main culprit in pathogenesis of amavata is ama, which is formed due to defective metabolism.

\section{Pathogenesis of Amavata}

Virudhahara and mandagni generates ama which gets mixed with aggravated vata. This ama is spread all over the body by dhamanis (vessels). When it reaches to shleshmasthana like joints, it produces the disease amavata. Simultaneously, ama also aggravates tridosha and when takes seat of trika (e.g. sacrum, shoulder girdle) produces amavata.

\section{Pathogenesis of Rheumatoid Arthritis}

Enteropathy creates antigens of GIT origin. Antibodies produced in response to these antigens produce antigenantibody reaction which cause immune-inflammation in connective tissues and produce rheumatoid arthritis. Here enteropathy may be due to improper functioning of digestive fire i.e. mandagni ${ }^{21}$.

\section{Ama as Free Radicals}

There are some views suggesting that free radicals are pathologically correlated with ama. In this regard it is said that property and manifestation of free radicals are similar to those of ama. ${ }^{22}$ Free radicals are unstable chemicals formed in the body during normal metabolism or exposure to environmental toxins such as air, food and water pollution. Free radicals help our body to generate energy and fight infection, but when we have too many free radicals they attack healthy cells causing them to age 
prematurely. These free radicals and other reactive oxygen species such as super oxides, hydrogen peroxide, and hydroxyl radicals are molecular species capable of independent existence that contain an unpaired electron in an atomic orbital. They are unstable chemicals formed in the body and can cause degenerative changes and other diseases like cancer, myocardial infarction etc. ${ }^{23}$ Free radicals also play an important role in a number of biological processes such as intracellular killing of bacteria by phagocytic cells like granulocyte and macrophages. Superoxide, nitric oxide and their reaction products regulate many processes such as control of vascular tone and then blood pressure. They also play a key role in intermediary metabolism of various biological compounds. Such radicals can even be messenger in a process dubbed redox reaction. ${ }^{24} \mathrm{O}_{2}^{-}$and $\mathrm{H}_{2} \mathrm{O}_{2}$ are oxidants that are effective bactericidal agents in conjunction with neutrophils. ${ }^{25}$ So above description of free radicals show that these species are not only harmful to the body but they are beneficiary too. On the contrary, ama is always pathological even in a small amount either accumulated or not. Whenever there will be formation of ama it will cause pathology and show its symptoms more or less thereby. So this correlation puts a question mark. However free radicals are also a by-product of metabolism.

\section{CONCLUSION}

Summing up above explanations it can be concluded that main factor concerned in the formation of ama is mandagni. Dietetic indiscretions and emotional stresses contribute to the formation of ama. These may impair the effective functioning of the neuro-humoral mechanism responsible for proper secretion of digestive juices. Ama is produced also due to accumulation of by-products of metabolism as well as metabolic waste not properly eliminated or utilized in the body. Here it is noteworthy that whenever there will be improper metabolism due to impaired functioning of agni then only ama will be formed. In modern parlance, ama may be referred to be intermediary by-products of metabolism which have tendency to block the microchannels of different system of the body. This can be compared with the accumulation of lipofuscin; amyloid bodies advanced glycation end products (AGE) and modified proteins. This process is an outcome of the deviation of main metabolic pathway in the direction to form defective metabolic end products. Increase in the normal values of blood urea, sugar, uric acids etc. may be understood as an ama condition. Ama formation due to mandagni is the main factor in amavata. The etiologies behind this mandagni are many like physical or life style borne, mental, environmental or seasonal variations.

One can allay so many diseases by balancing one's physical and mental state following a wholesome food habit and life style.

\section{REFERENCES}

1. Agnivesha. Charaka Samhita. Sutrasthana 30/26. Rajeshwar Dutt Shastri et al, Editors. Varanasi: Choukhambha Bharati Academy; Reprinted; 2005. p. 587.

2. Sushruta. Sushruta Samhita. Sutrasthana 15/48. Shastri Ambikadutta, Editor. Varanasi: Choukhamabha Sanskrit Sansthan; Reprinted; 2007. p. 56.

3. Sushruta. Sushruta Samhita. Sutrasthana 15/3. Shastri Ambikadutta, Editor. Varanasi: Choukhamabha Sanskrit Sansthan; Reprinted; 2007. p. 56.

4. Agnivesha. Charaka Samhita. Sharma PV, Editor. Chikitsasthana 15/3-4.Varanasi: Choukhambha Orientalia; Reprinted; 2008. p. 249.

5. Agnivesha. Charaka Samhita. Sharma PV, Editor. Chikitsasthana 15/5.Varanasi: Choukhambha Orientalia; Reprinted; 2008. p. 250.

6. Vagbhata. Astanga Hridaya. Gupta Atridev, Editor. Nidanasthana 12/1. Varanasi: Choukhambha Sanskrit Series; 1970. p. 263.

7. Vagbhata. Astanga Hridaya. Gupta Atridev, Editor. Sutrasthana 13/25. Varanasi: Choukhambha Sanskrit Series; 1970. p. 99.

8. Vagbhata. Astanga Hridaya. Gupta Atridev, Editor. Sutrasthana 13/26.Varanasi: Choukhambha Sanskrit Series; 1970. p. 99.

9. Vijayrakshita. Madhukosha (commentary on Madhava Nidana). Upadhyaya Yadunandana, Editor. Amavata Nidana. Varanasi: Choukhambha Sanskrit Sansthana; Reprinted; 2005. p. 509.

10. Vagbhata. Astanga Hridaya. Gupta Atridev, Editor. Sutrasthana 12/22. Varanasi: Choukhambha Sanskrit Series; 1970. p. 91.

11. Agnivesha. Charaka Samhita. Sharma PV, Editor. Vimanasthana 2/8-9.Varanasi: Choukhambha Orientalia; Reprinted; 2008. p. 311.

12. Agnivesha. Charaka Samhita. Sharma PV, Editor. Chikitsasthana 15/42-44.Varanasi: Choukhambha Orientalia; Reprinted; 2008. p. 252

13. Vagbhata. Astanga Hridaya. Gupta Atridev, Editor. Sutrasthana 13/26. Varanasi: Choukhambha Sanskrit Series; 1970. p. 99.

14. Sushruta. Sushruta Samhita. Shastri Ambikadutta, Editor Uttartantra 56/10.Varanasi: Choukhamabha Sanskrit Sansthan; Reprinted; 2009. p. 528.

15. Byadgi PS. Ayurvediya Vikriti Vijnana and Roga Vijnana Vol-1. Ama. New Delhi: Chaukhambha Publications; 2007. p. 192-193.

16. Byadgi PS. Ayurvediya Vikriti Vijnana and Roga Vijnana Vol-1. Ama. New Delhi: Chaukhambha Publications; 2007. p. 195.

17. Dwarkanath C. Introduction to Kayachikitsa. $2^{\text {nd }}$ edition. the concept of Ama and Sama Varanasi: Choukhambha Orientalia; 1986. p. 69.

18. Madhavakara. Madhava Nidana. Yadunadan Upadhyaya, Editor. Amavata Nidana.Varanasi: Choukhambha Sanskrit Sansthana; 2005. p. 511.

19. Madhavakara. Madhava Nidana. Yadunadan Upadhyaya, Editor. Amavata Nidana. Varanasi: Choukhambha Sanskrit Sansthana; 2005. p. 508.

20. Madhavakara. Madhava Nidana. Yadunadan Upadhyaya, Editor. Amavata Nidana.Varanasi: Choukhambha Sanskrit Sansthana; 2005. p. 509.

21. Singh RH. Kayachikitsa, Vol. II. Amavata. New Delhi: Choukhambha Sanskrit Pratisthana; 2004. p. 536.

22. Kumar Baldev, Dave Hetal, Kumari Madhuri. Pathological Correlation between Ama and Free Radicals with Special Reference to Madhumeha. The Journal of Research and Education in Indian Medicine 2008; xiv-2: 61-64.

23. Wikipedia. Radical [Internet]. 2013 [Modified on 2013 July 12; cited on 2013 August 8]. Available from: en.wikipedia. org/wiki/Radical_(chemistry).

24. Lobo V, Patil A, Pathak A, Chandra N. Free radicals, antioxidants and functional foods: Impact on human health. Pharmacognosy Review [Internet] Available from: www.ncbi.nlm.nih.gov/ pmc/article/pmc 3249911 2010; 4(8): 118-126.

25. Ganong F William. Review of Medical Physiology. $22^{\text {nd }}$ edition. Circulating Body Fluids, chapter 27.New Delhi: Mc Graw Hill; 2007. p. 518 .

Cite this article as:

Mishra Pramod Kumar, Rai N.P. Ama a metabolic by product with special reference to Amavata. Int. J. Res. Ayurveda Pharm. 2013;4(5):685-687 http://dx.doi.org/10.7897/2277-4343.04511 